\title{
FGF-2 suppresses cellular senescence of human mesenchymal stem cells by down-regulation of TGF- $\beta 2$
}

\author{
Tomomi Ito ${ }^{\mathrm{a}, \mathrm{b}}$, Rumi Sawada ${ }^{\mathrm{a}}$, Yoko Fujiwara ${ }^{\mathrm{b}}$, Yousuke Seyama ${ }^{\mathrm{b}}$, \\ and Toshie Tsuchiya ${ }^{a}{ }^{*}$
}

a Division of Medical Devices, National Institute of Health Sciences, 1-18-1 Kamiyoga, Setagaya-ku, Tokyo 158-8501, Japan

${ }^{b}$ Graduate School of Humanities and Sciences, Ochanomizu University, 2-1-1, Otsuka, Bunkyo-ku, Tokyo 112-8610, Japan

*Corresponding author. Fax: +81-3-3700-9196.

E-mail address: tsuchiya@,nihs.go.jp (T. Tsuchiya). 


\section{ABSTRACT}

Human mesenchymal stem cells (hMSCs) are able to both self-replicate and differentiate

into a variety of cell types. Fibroblast growth factor-2 (FGF-2) stimulates the growth of

hMSCs in vitro, but its mechanisms have not been clarified yet. In this study, we

investigated whether cellular senescence was involved in the stimulation of hMSCs growth

by FGF- 2 and the expression levels of transforming growth factor- $\beta 1$ and $-\beta 2$ (TGF- $\beta \mathrm{s}$ ).

Because hMSCs were induced cellular senescence due to long-term culture, FGF-2 decreased

the percentage of senescent cells and suppressed G1 cell growth arrest through the

suppression of $\mathrm{p} 21^{\mathrm{Cip} 1}, \mathrm{p} 53$, and $\mathrm{p} 16^{\mathrm{INK} 4 \mathrm{a}}$ mRNA expression levels. Furthermore, the levels

of TGF- $\beta$ s mRNA expression in hMSCs were increased by long-term culture, but FGF-2

suppressed the increase of TGF- $\beta 2$ mRNA expression due to long-term culture. These

results suggest that FGF-2 suppresses the hMSCs cellular senescence dependent on the length

of culture through down-regulation of TGF- $\beta 2$ expression. 
Key Words: human mesenchymal stem cells; FGF-2; TGF- $\beta$; cellular senescence;

cyclin-dependent kinase inhibitors; RB.

\section{INTRODUCTION}

Mesenchymal stem cells (MSCs) are able to self-replicate and differentiate into a variety of

cell types such as osteoblasts, chondrocytes, adipocytes, and smooth muscle cells [1-5].

These capacities of MSCs have been used in studies of bone and cartilage regeneration [6-8].

One of the sources for human MSCs (hMSCs) is adult bone marrow. However, the ratio of

hMSCs in adult bone marrow is about one per one-hundred-thousand nucleated cells [6], and

the volume of bone marrow obtainable is limited. To secure the numbers of hMSCs

required for the regeneration of tissues, hMSCs obtained from bone marrow need to be

expanded in vitro.

Fibroblast growth factor-2 (FGF-2) is a cell growth factor involved in angiogenesis and 
tissue repair. FGF-2 maintains human bone marrow stromal cells in an immature state

during in vitro expansion [9-11]. In hMSCs, FGF-2 enhances growth and maintains the potential for multidifferentiation $[12,13]$. Thus, it is thought that FGF-2 is one of the effective factors in the regeneration of tissues.

Transforming growth factor- $\beta$ s (TGF- $\beta$ s) are multifunctional proteins that regulate cell growth, differentiation, migration, extracellular matrix production, angiogenesis, and immunosuppression [14]. TGF- $\beta$ s arrest the cell growth of epithelial cells and blood cells in the G1 phase through inhibition of G1 cyclin-dependent kinases (CDKs) $[15,16] . \quad$ It is reported that TGF- $\beta$ s down-regulate the c-myc oncogene and up-regulate the CDK inhibitors $\mathrm{p} 15^{\mathrm{INK} 4 \mathrm{~b}}$ and $\mathrm{p} 21^{\mathrm{Cip} 1}[17,18]$.

Cellular senescence is one of the tumor suppressor functions of normal human cells [19].

Senescent cells induce cell growth arrest in the G1 phase and a change in morphology and metabolism. Some of the senescence-associated changes that are common to many different 
cell types include cellular enlargement, increased lysosome biogenesis, and expression of a

$\beta$-galactosidase that has a $\mathrm{pH}$ optimum of 6 (senescence-associated $\beta$-galactosidase or

SA- $\beta$-Gal) [20]. It is thought that two mechanisms of cellular senescence exist: intrinsic

senescence dependent on telomere shortening and extrinsic senescence independent of it.

The former is induced by activation of $\mathrm{p} 53$ and an increase of expression levels of $\mathrm{p} 21^{\mathrm{Cip} 1}$, a

well-recognized p53 target gene [19, 21-23]. The latter is induced by various culture

stresses and the up-regulation of $\mathrm{p} 16^{\mathrm{INK} 4 \mathrm{a}}$ expression [24-26]. Activation of cyclin-CDK

complex by suppression of expression of the CDK inhibitors $\mathrm{p} 21^{\mathrm{Cip} 1}, \mathrm{p} 53, \mathrm{p} 16^{\mathrm{INK} 4 \mathrm{a}}$ promotes

phosphorylation of retinoblastoma proteins $(\mathrm{pRB})$. Phosphorylation of $\mathrm{pRB}$ is required for the

progress from the cellular G1 phase to the S phase.

Our previous studies have shown that hMSCs growth was decreased and the level of

TGF- $\beta$ mRNA expression increased during long-term subculture in vitro [27]. In this study,

we investigated whether the decrease of growth ability in long-term culture involves cellular 
senescence through changes in the expressions of TGF- $\beta$ and the CDK inhibitors. Moreover, we attempted to stimulate hMSCs growth using FGF-2 and investigated whether FGF-2

affected cellular senescence and the expressions of TGF- $\beta$ s, cell growth suppression factors.

\section{MATERIALS AND METHODS}

\section{Cell culture}

hMSCs were obtained from Cambrex Bio Science Walkersville, Inc. (Walkersville, MD) and seeded in MSCGM medium (Cambrex Bio Science Walkersville) at 5,000 cells $/ \mathrm{cm}^{2}$ with or without $1 \mathrm{ng} / \mathrm{ml}$ FGF-2 (BD Biosciences, Bedford, MA). FGF-2 was also added when the culture medium was changed every 2-3 days. The concentration of FGF-2 used in this study was based on a previous report [13]. The cells were maintained in humidified incubators at $37^{\circ} \mathrm{C}$ with $5 \% \mathrm{CO}_{2}$.

\section{TGF- $\beta$ treatment}


TGF- $\beta 1$ and TGF- $\beta 2$ (human, recombinant) were purchased from Sigma (St. Louis, MO).

TGF- $\beta 1$ or TGF- $\beta 2$ at $5 \mathrm{ng} / \mathrm{ml}$ was added to the culture medium without FGF-2 for five days.

The concentraion of TGF- $\beta$ s used was determined by a previously published study [28].

\section{SA- $\beta$-Gal staining}

SA- $\beta$-Gal staining was performed using a Senescence-associated $\beta$-Galactosidase Staining

Kit (Cell Signaling, Beverly, MA) following the manufacturer's protocol.

\section{BrdU incorporation}

The incorporation of BrdU during DNA synthesis was measured using a Cell Proliferation

ELISA kit with BrdU (Roche Diagnostics, Penzberg, Germany) following the manufacturer's protocol.

\section{Flow cytometry analysis}

hMSCs were removed from the culture dish with trypsin/EDTA (Cambrex Bio Science

Walkersville), then stained using a CycleTEST ${ }^{\mathrm{TM}}$ PLUS DNA Reagent Kit (BD Biosciences, 
San Jose, CA) following the manufacturer's protocol. Propidium iodide (PI) fluorescence was measured using a FACSCalibur flow cytometer (BD Biosciences). The data were analyzed using FlowJo (Tree Star, Inc., Ashland, OR).

\section{Quantitative real-time RT-PCR}

PCRs of $\mathrm{p} 53$, TGF- $\beta 1$, and TGF- $\beta 2$ were performed for 35 cycles under the following conditions: denaturation at $95^{\circ} \mathrm{C}$ for $10 \mathrm{~s}$, annealing at $68^{\circ} \mathrm{C}$ for $10 \mathrm{~s}$, and extension at $72^{\circ} \mathrm{C}$ for $16 \mathrm{~s}$; of $\mathrm{p} 16: 95^{\circ} \mathrm{C}$ for $10 \mathrm{~s}, 60^{\circ} \mathrm{C}$ for $10 \mathrm{~s}, 72^{\circ} \mathrm{C}$ for $6 \mathrm{~s}$; and $\mathrm{p} 21: 95^{\circ} \mathrm{C}$ for $10 \mathrm{~s}, 60^{\circ} \mathrm{C}$ for $10 \mathrm{~s}, 72^{\circ} \mathrm{C}$ for $10 \mathrm{~s}$, using the LightCycler real-time PCR System (Roche Diagnostics, Tokyo, Japan). The primers for $\mathrm{p} 53$, TGF- $\beta 1$, TGF- $\beta 2$, and GAPDH were from a LightCycler-Primer Set (Search LC GmbH, Heidelberg, Germany). The primers for p16 and p21 were 5'-CACTCACGCCCTAAGC-3' and 5'-GCAGTGTGACTCAAGAGAA-3', and 5'-TTGATTAGCAGCGGAACA-3' and 5'-GGAGAAACGGGAACCAG-3', respectively.

\section{Western blotting}


A mouse monoclonal antibody against $\mathrm{pRb}$ and a rabbit polyclonal antibody against

phospho-pRb were purchased from Cell Signaling (Beverly, MA). The rabbit polyclonal

antibodies against TGF- $\beta 1$, TGF- $\beta 2$, and GAPDH were purchased from Santa Cruz

Biotechnology, Inc. The bands were quantified using ImageQuant ${ }^{\mathrm{TM}} \mathrm{TL}$ (GE Healthcare UK

Ltd., Buckingham, England).

\section{RESULTS}

\section{TGF- $\beta$ induced cellular senescence in hMSCs}

To investigate the effects of TGF- $\beta$ on cellular senescence, hMSCs were cultured in MSCGM

medium supplemented with TGF- $\beta 1$ or TGF- $\beta 2$, and then SA- $\beta-$ Gal staining was performed

and incorporation of BrdU, an analog of thymidine, was measured. One day after TGF- $\beta 1$

or TGF- $\beta 2$ treatment, hMSCs had a fibroblast-like morphology (Fig. 1C and E) similar to the

control (Fig. 1A). Five days after TGF- $\beta 1$ or TGF- $\beta 2$ treatment, hMSCs had acquired a 
depressed morphology, and some of them were stained blue by SA- $\beta$-Gal staining (Fig. 1D

and $\mathrm{F}$, arrows). In the control, however, stained cells were rarely observed (Fig. 1B). Five

days after TGF- $\beta 1$ and TGF- $\beta 2$ treatment, BrdU incorporation had decreased in comparison

with the control (Fig. 1G). Furthermore, to confirm whether TGF- $\beta$ s induced G1 cell

growth arrest in hMSCs, cell cycle analysis was performed using flow cytometry. As shown

in Fig. $1 \mathrm{H}$, TGF- $\beta 1$ and TGF- $\beta 2$ increased the percentage of cells in G1 phase, and decreased

it in $\mathrm{S}$ and $\mathrm{G} 2$ phases. Then, the mRNA expression levels of $\mathrm{p} 16^{\mathrm{INK} 4 \mathrm{a}}, \mathrm{p} 21^{\mathrm{Cip} 1}$, and $\mathrm{p} 53$,

$\mathrm{CDK}$ inhibitors of the G1 phase, and the protein expression levels of $\mathrm{pRB}$ were measured

after five days of TGF- $\beta 1$ or TGF- $\beta 2$ treatment. TGF- $\beta$ s increased all three mRNA

expression levels (Fig. 1I-K). On the other hand, the phosphorylated pRB (ppRB)

expression was decreased by both TGF- $\beta$ s (Fig. 1L). These results suggest that cellular

senescence of hMSCs is induced through G1 growth arrest by TGF- $\beta 1$ and TGF- $\beta 2$.

FGF-2 suppressed hMSCs cellular senescence 
To investigate whether stimulation of hMSCs growth by FGF-2 was involved in the suppression of cellular senescence, hMSCs were stained with SA- $\beta$-Gal after culture with or without FGF-2 (FGF-2(+) or FGF-2(-)) for 10 or 50 days. After 10 days' culture in FGF-2(-), hMSCs had a fibroblast-like morphology, and $20.5 \%$ of the cells were stained blue by SA- $\beta$-Gal (Fig. 2 A); however, after 50 days' culture, hMSCs had developed a depressed morphology, and $57.6 \%$ of the cells were stained blue (Fig. 2C, arrows). After 10 or 50 days' culture in FGF-2(+), hMSCs morphology had a fibroblast-like morphology; moreover, $35.8 \%$ or $27.3 \%$ of the cells were stained blue, respectively (Fig. 2B and D). BrdU incorporation into hMSCs after 50 days' culture was $40 \%$ lower than after 10 days' culture in FGF-2(-) but not in FGF-2(+) (Fig. 2E). Furthermore, we investigated the effects of FGF-2 on the cell cycle. After 50 days' culture in FGF-2(-), the number of cells in the G1 phase was increased, but not after culture in FGF-2(+) (Fig. 2F).

The mRNA expression levels of $\mathrm{p} 16^{\mathrm{INK} 4 \mathrm{a}}, \mathrm{p} 21^{\mathrm{Cip} 1}$, and $\mathrm{p} 53$ and the expression levels of $\mathrm{pRB}$ 
in hMSCs were measured after culture for 10 or 50 days in FGF-2(-) or FGF-2(+). After 50

days' culture in FGF-2(-), the mRNA expression levels of $\mathrm{p} 16^{\mathrm{INK} 4 \mathrm{a}}, \mathrm{p} 21^{\mathrm{Cip} 1}$, and $\mathrm{p} 53$ were significantly higher than after 10 days' culture, but not after culture in FGF-2(+) (Fig. 3A-C).

On the other hand, after 50 days' culture in FGF-2(-), the expression levels of total pRB and ppRB were decreased compared with after 10 days' culture, but not after culture in FGF-2(+)

(Fig. 3D). These results suggest that FGF-2 suppresses hMSCs cellular senescence

depending on the length of culture.

\section{FGF-2 influenced TGF- $\beta$ mRNA expression in hMSCs}

To investigate the effects of FGF-2 on TGF- $\beta$ mRNA and protein expression levels in hMSCs,

their levels were measured after culture for 1, 10, or 50 days in FGF-2(-) or FGF-2(+).

After culture for 50 days in both FGF-2(-) and FGF-2(+), TGF- $\beta 1$ mRNA expression levels of hMSCs had increased in comparison with culture for 1 and 10 days (Fig. 4A). On the other hand, TGF- $\beta 2$ mRNA expression levels were higher after 50 days' culture in FGF-2(-) 
than after 10 days, but not after culture in FGF-2(+) (Fig. 4B). Comparing 50 days' culture

with 10 days' culture, the changes of TGF- $\beta 1$ and TGF- $\beta 2$ protein expression levels

paralleled the results of mRNA expression levels (Fig. 4C). These results suggest that

FGF-2 has no effect on TGF- $\beta 1$ expression levels in hMSCs, but inhibits the increase of

TGF- $\beta 2$ expression, depending on the length of culture.

\section{DISCUSSION}

hMSCs are one of the human tissue stem cells, and they maintain the homeostasis of bone

and cartilage. hMSCs are found in adult human bone marrow, and those obtained from

patients until late adulthood still exhibit osteogenic potency [29]. Thus, it is thought that

hMSCs maintain self-renewal and differentiation capacity in vivo throughout life. However,

our previous studies have shown that the self-renewal potency of hMSCs is decreased by

long-term culture in vitro [27]. The results of this study suggest that cellular senescence 
was induced in hMSCs (Fig. 2) following G1 cell growth arrest through increases of p16 ${ }^{\mathrm{INK} 4 \mathrm{a}}$, p2 $1^{\text {Cip1 }}$, and p53 mRNA expression levels (Figs. 2 and 3) due to long-term culture in vitro.

Since it was reported that cellular senescence was induced by the stress of culture [30],

hMSCs would also be subject to finite proliferation due to many unknown stresses in our

studies.

It was reported that TGF- $\beta 1$ induced changes in hMSC morphology [28]. In the present

study, after five days' treatment with TGF- $\beta 1$ and TGF- $\beta 2$ (TGF- $\beta$ s), hMSCs were spread out,

some of the cells were stained blue by SA- $\beta$-Gal staining (Fig. 1A-F), and they had decreased

DNA replicative potential (Fig. 1G). In human prostate stromal cells, TGF- $\beta 1$ induced

similar morphological changes, but had no effect on cellular senescence [31]. However, we

hypothesize that the changes in hMSC morphology induced by TGF- $\beta$ s were due to cellular

senescence because the conditions of our study differed from those of previous studies:

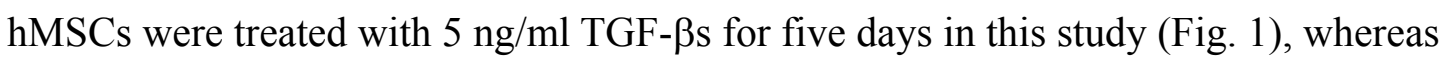


hMSCs were treated with $1 \mathrm{ng} / \mathrm{ml} \mathrm{TGF-} \beta 1$ for three days in the previous study [31].

Moreover, the responses to TGF- $\beta$ stimulation may depend on the kind of cell.

We considered that the cellular senescence induced by TGF- $\beta$ s is involved in G1 growth

arrest through the increase of CDK inhibitors (p16 ${ }^{\mathrm{INK} 4 \mathrm{a}}, \mathrm{p} 21^{\mathrm{Cip} 1}$, and $\left.\mathrm{p} 53\right)$. We observed that the number of cells in the G1 phase (Fig. 1) and the mRNA expression levels of p16 ${ }^{\mathrm{INK} 4 \mathrm{a}}$, $\mathrm{p} 21^{\mathrm{Cip} 1}$, and $\mathrm{p} 53$ were increased by TGF- $\beta \mathrm{s}$ (Fig. $\left.2 \mathrm{~A}-\mathrm{C}\right) . \quad$ It has been reported that TGF- $\beta$

increased the expression levels of $\mathrm{p} 21^{\mathrm{Cip} 1}[17]$ but not $\mathrm{p} 16^{\mathrm{INK} 4 \mathrm{a}}[18,32]$. However, the increase of $\mathrm{p} 16^{\mathrm{INK} 4 \mathrm{a}}$ expression levels was important for the irreversible stop of the cell cycle [26]. Based on our results in this study, we support the latter report.

The phosphorylation of $\mathrm{pRB}$, which is regulated by CDK inhibitors, accompanies the G1/S transition $[16,33]$. We also showed that the expression levels of total $\mathrm{pRB}$ and $\mathrm{ppRB}$ were decreased by TGF- $\beta$ s treatment (Fig. 2D). It has been reported that TGF- $\beta 1$ decreased RB gene expression [34]; moreover, TGF- $\beta 1$ inhibited pRB phosphorylation $[15,35]$. We 
suspect that ppRB expression decreased for two reasons: the relative decrease due to the inhibition of total pRB expression by TGF- $\beta$ s and the decrease of $\mathrm{pRB}$ phosphorylation due to the increase of CDK inhibitors by TGF- $\beta$ s.

FGF-2, one of the cell growth factors, efficiently increases the number of hMSCs [12, 13], but its mechanisms have unknown yet. In this study, we showed that the cell growth arrest in the G1 phase was suppressed by FGF-2 through the suppression of $\mathrm{p} 16^{\mathrm{INK} 4 \mathrm{a}}, \mathrm{p} 21^{\mathrm{Cip} 1}$, and p53 mRNA expression levels and the increase of ppRB expression levels (Figs. 2 and 3). Furthermore, the expression levels of TGF- $\beta 1$ and $\beta 2$ mRNA were increased by long-term culture (Fig. 4A and B), in agreement with our previous studies [27]. However, FGF-2 suppressed the increase of TGF- $\beta 2$ mRNA expression levels (Fig. 4B). FGF-2 also consistently suppressed the increase of TGF- $\beta 2$ protein expression levels in long-term culture (Fig. 4C). It was reported that TGF- $\beta 2$ inhibited FGF-2-induced proliferation of corneal endothelial cells [36]. Based on our results and that report, we consider that FGF-2 
suppressed cellular senescence through down-regulation of TGF- $\beta 2$ expression in hMSCs

(Fig. 4D).

After 50 days' culture with FGF-2, pRB protein expression levels were remarkably

increased, ppRB expression levels were up-regulated (Fig. 3D), and TGF- $\beta 2$ expression was

down-regulated as well (Fig.4B). Moreover, TGF- $\beta$ s remarkably decreased the $\mathrm{pRB}$

expression levels and induced cellular senescence (Fig. 1). It was also reported that

senescence in cells induced reduction of RB protein levels [37]. Therefore, the increase of

pRB expression levels when FGF-2 suppressed hMSC senescence may be involved in the

down-regulation of TGF- $\beta 2$ (Fig.4D).

In conclusion, long-term culture induced cellular senescence by arresting cell growth in the

G1 phase and increasing expression levels of TGF- $\beta$ s in hMSCs. On the other hand, FGF-2

suppressed cellular senescence and down-regulated TGF- $\beta 2$ expression in hMSCs. We

consider that the suppression of TGF- $\beta 2$ expression is important in the suppression of cellular 
senescence of hMSCs by FGF-2. However, after 150 days' culture, hMSCs no longer

maintained self-renewal capacity, and the expression levels of TGF- $\beta 2$ were increased in

spite of the addition of FGF-2 (data not shown). These results suggest that FGF-2 delayed

the decrease of self-renewal capacity due to long-term culture in hMSCs. TGF- $\beta 2$ may be

useful for the maintenance of self-renewal capacity in hMSCs. The data in this study will

advance the knowledge of hMSC biology, and allow us to realize safe and efficient clinical

applications of hMSCs.

\section{REFERENCES}

[1] M.F. Pittenger, A.M. Mackay, S.C. Beck, R.K. Jaiswal, R. Douglas, J.D. Mosca, M.A.

Moorman, D.W. Simonetti, S. Craig, D.R. Marshak, Multilineage potential of adult human mesenchymal stem cells, Science 284 (1999) 143-147.

[2] A.I. Caplan, S.P. Bruder, Mesenchymal stem cells: building blocks for molecular 
medicine in the 21 st century, Trends Mol. Med. 7 (2001) 259-264.

[3] S. Gojo, N. Gojo, Y. Takeda, T. Mori, H. Abe, S. Kyo, J. Hata, A. Umezawa, In vivo cardiovasculogenesis by direct injection of isolated adult mesenchymal stem cells, Exp.

Cell Res. 288 (2003) 51-59.

[4] S. Wakitani, T. Saito, A.I. Caplan, Myogenic cells derived from rat bone marrow mesenchymal stem cells exposed to 5-azacytidine, Muscle Nerve 18 (1995) 1417-1426.

[5] J.P. Darwin, Marrow stromal cells as stem cells for nonhematopoietic tissues, Science 276 (1997) 71-74.

[6] H. Ohgushi, A.I. Caplan, Stem cell technology and bioceramics: from cell to gene engineering, J. Biomed. Mater. Res. 48 (1999) 913-927.

[7] H. Petite, V. Viateau, W. Bensaid, A. Meunier, C. Pollak, M. Bourguignon, K. Oudina, L. Sedel, G. Guillemin, Tissue-engineered bone regeneration, Nat. Biotechnol. 18 (2000) 959-963. 
[8] M. Ochi, N. Adachi, N. Hiroo, S. Yamada, Y. Ito, M. Agung, Articular cartilage repair using tissue engineering technique-novel approach with minimally invasive procedure, Artif. Organs 28 (2004) 28-32.

[9] M. Mastrogiacomo, R. Cancedda, R. Quarto, Effect of different growth factors on the chondrogenic potential of human bone marrow stromal cells, Osteoarthritis Cartilage 9 Suppl. A (2001) S36-40.

[10] I. Martin, A. Muraglia, G. Campanile, R. Cancedda, R. Quarto, Fibroblast growth factor-2 supports ex vivo expansion and maintenance of osteogenic precursors from human bone marrow, Endocrinology 138 (1997) 4456-4462.

[11] G. Bianchi, A. Banfi, M. Mastrogiacomo, R. Notaro, L. Luzzatto, R. Cancedda, R. Quarto, Ex vivo enrichment of mesenchymal stem cell progenitors by fibroblast growth factor 2, Exp. Cell Res. 287 (2003) 98-105.

[12] L.A. Solchaga, K. Penick, J.D. Porter, V.M. Goldberg, A. I. Caplan, J.F. Welter, FGF-2 
enhances the mitotic and chondrogenic potentials of human adult bone marrow-derived

mesenchymal stem cells, J. Cell Physiol. 203 (2005) 398-409.

[13] S. Tsutsumi, A. Shimazu, K. Miyazaki, H. Pan, C. Koike, E. Yoshida, K. Takagishi, Y. Kato, Retention of multilineage differentiation potential of mesenchymal stem cells during proliferation in response to FGF, Biochem. Biopys. Res. Commun. 288 (2001) 413-419.

[14] K. Miyazono, H. Suzuki, T. Imamura, Regulation of TGF- $\beta$ signaling and its roles in progression of tumors, Cancer Sci. 94 (2003) 230-234.

[15] M. Laiho, J.A. DeCaprio, J.W. Ludlow, D.M. Livingston, J. Massague, Growth inhibition by TGF- $\beta$ linked to suppression of retinoblastoma protein phosphorylation, Cell $62(1990) 175-185$.

[16] J. Charles, M.R. Jeames, CDK inhibitors: positive and negative regulators of G1-phase progression, Genes \& Development 13 (1999) 1501-1512.

[17] J. Massague, S.W. Blain, R.S. Lo, TGF- $\beta$ signaling in growth control, cancer, and 
heritable disorders, Cell 103 (2000) 295-309.

[18] W. Zhou, I. Park, M. Pins, J.M. Kozlowski, B. Jovanovic, J. Zhang, C. Lee, K. Ilio, Dual regulation of proliferation and growth arrest in prostatic stromal cells by transforming growth factor- $\beta 1$, Endocrinology 144 (2003) 4280-4284.

[19] K. Itahana, G. Dimri, J. Campisi, Regulation of cellular senescence by p53, Eur. J. Biochem. 268 (2001) 2784-2791.

[20] G.P. Dimri, X. Lee, G. Basile, G. Scott, C. Roskelley, E.E. Medrano, M. Linskens, I. Rubelj, O. Pereira-Smith, M. Peacocke, J. Campisi, A biomarker that identifies senescent human cells in culture and in aging skin in vivo, Proc. Natl. Acad. Sci. USA 92 (1995) 9363-9367.

[21] W.S. el-Deiry, T. Tokino, V.E. Velculescu, D.B. Levy, R. Parsons, J.M. Trent, D. Lin, W.E. Mercer, K.W. Kinzler, B. Vogelstein, WAF1, a potential mediator of p53 tumor suppression, Cell 75 (1993) 817-825. 
[22] J. LaBaer, M.D. Garrett, L.F. Stevenson, J.M. Slingerland, C. Sandhu, H.S. Chou, A.

Fattaey, E. Harlow, New function activities for the p21 family of CDK inhibitors, Genes.

Dev. 11 (1997) 847-862.

[23] K. Itahana, G.P. Dimri, E. Hara, Y. Itahana, Y. Zou, P.Y. Desprez, J. Campisi, A role for p53 in maintaining and establishing the quiescence growth arrest in human cells, J. Biol.

Chem. 277 (2002) 18206-18214.

[24] T. Kiyono, S.A. Foster, J.I. Koop, J.K. McDougall, D.A. Galloway, A.J. Klingelhutz, Both $\mathrm{Rb} / \mathrm{p} 16^{\mathrm{INK} 4 \mathrm{a}}$ inactivation and telomerase activity are required to immortalize human epithelial cells, Nature 396 (1998) 84-88.

[25] J.G. Rheinwald, W.C. Hahn, M.R. Ramsey, J.Y. Wu, Z. Guo, H. Tsao, M. Luca, C. Catricala, K.M. O'Toole, A two-stage, p16 (INK4A)- and p53-dependent keratinocyte senescence mechanism that limits replicative potential independent of telomere status, Mol.

Cell Biol. 22 (2002) 5157-5172. 
[26] C.M. Beausejour, A. Krtolica, F. Galimi, M. Narita, S.W. Lowe, P. Yaswen, J. Campisi,

Reversal of human cellular senescence: roles of the p53 and p16 pathways, EMBO J. 22

(2003) 4212-4222.

[27] R.Sawada, T. Ito, T. Tsuchiya, Changes in expression of genes related to cell

proliferation in human mesenchymal stem cells during in vitro culture in comparison with

cancer cells, J. Artif. Organs 9 (2006) 179-184

[28] D. Wang, J.S. Park, J.S. Chu, A. Krakowski, K. Luo, D. J. Chen, S. Li, Proteomic profiling of bone marrow mesenchymal stem cells upon transforming growth factor $\beta 1$ stimulation, J. Biol. Chem. 279 (2004) 43725-43734.

[29] H.V. Leskela, J. Risteli, S. Niskanen, J. Koivunen, K.K. Ivaska, P. Lehenkari, Osteoblast recruitment from stem cells does not decrease by age at late adulthood, Biochem. Biopys.

Res. Commun. 311 (2003) 1008-1013.

[30] K. Ito, A. Hirao, F. Arai, S. Matsuoka, K. Takubo, I. Hamaguchi, K. Nomiyama, K. 
Hosokawa, K. Sakurada, N. Nakagata, Y. Ikeda, T.W. Mak, T. Suda, Regulation of

oxidative stress by ATM is required for self-renewal of haematopoietic stem cells, Nature

431 (2004) 997-1002.

[31] G. Untergasser, R. Gander, C. Lilg, E.P. Lepperdinger, P. Berger, Profiling molecular targets of TGF- $\beta 1$ in prostate fibroblast-to-myofibroblast transdifferentiation, Mech.

Ageing Dev. 126 (2005) 59-69.

[32] R. Tremain, M. Marko, V. Kinnimulki, H. Ueno, E. Bottinger, A. Glick, Defects in

TGF- $\beta$ signaling overcome senescence of mouse keratinocytes expressing $v$-ras ${ }^{\mathrm{Ha}}$,

Oncogene 19 (2000) 1698-1709.

[33] R.A. Weinberg, The retinoblastoma protein and cell cycle control, Cell 81 (1995)

323-330.

[34] R.E. Herrera, T.P. Makela, R.A. Weinberg, TGF beta-induced growth inhibition in primary fibroblasts requires the retinoblastoma protein, Mol. Biol. Cell. 7 (1996) 
$1335-1342$.

[35] Z. Yan, S. Hsu, S. Winawer, E. Friedman, Transforming growth factor beta 1

(TGF-beta1) inhibits retinoblastoma gene expression but not $\mathrm{pRB}$ phosphorylation in

TGF-beta 1-growth stimulated colon carcinoma cells, Oncogene 7 (1992) 801-805.

[36] J. Lu, Z. Lu, P. Reinach, J. Zhang, W. Dai, L. Lu, M. Xu, TGF-beta2 inhibits AKT

activation and FGF-2-induced corneal endothelial cell proliferation, Exp. Cell Res. 312

(2006) 3631-3640.

[37] Q.M. Chen, V.C. Tu, J. Liu, Measurements of hydrogen peroxide iduced premature senescence: senescence-associated beta-galactosidase and DNA synthesis index in human diploid fibroblasts with down-regulated p53 or Rb, Biogerontology 1 (2000) 335-339. 


\section{LEGENDS}

Figure 1. TGF- $\beta 1$ and $\beta 2$ induce cellular senescence through G1 cell cycle arrest in hMSCs.

hMSCs were maintained as an untreated control or treated with $5 \mathrm{ng} / \mathrm{ml}$ TGF- $\beta 1$ or TGF- $\beta 2$

for 5 days. (A-F): hMSCs were performed SA- $\beta$-Gal staining 1 or 5 days after TGF- $\beta$

treatment (Day 1 or 5). The arrows in D and $\mathrm{F}$ indicate the senescent cells stained blue. The

scale bar is $100 \mu \mathrm{m}$. (G): BrdU incorporation into hMSCs was assayed at Days 1, 3, and 5.

Each point represents quantities relative to the untreated control at Day 1. (H): After 3 days'

culture with or without TGF- $\beta 1$ or TGF- $\beta 2$, cells were removed from the culture dish with

trypsin/EDTA, fixed, stained for DNA with PI, and analyzed by flow cytometry (y-axis, cell

count; $\mathrm{x}$-axis, PI intensity). (I-K): p16 ${ }^{\mathrm{INK} 4 \mathrm{a}}(\mathrm{A}), \mathrm{p} 53$ (B), and $\mathrm{p} 21^{\mathrm{Cip} 1}(\mathrm{C})$ mRNA expression

levels measured using real time RT-PCR. The relative levels of gene expression of target

mRNA were normalized to GAPDH expression. Values are the mean $\pm \mathrm{SD}$ of three

experiments $\left({ }^{*} P<0.05\right)$. (L): Total $\mathrm{pRB}$ and phospho-pRB proteins detected using Western 
blot analysis.

Figure 2. FGF-2 suppresses cellular senescence through G1 cell cycle arrest due to long-term culture. hMSCs were maintained in the medium in the presence or absence of FGF-2 (1 ng/ml). (A-D): hMSCs were performed SA- $\beta$-Gal staining after culture for 10 days or 50 days (Day 10 or 50). The arrows in $\mathrm{C}$ indicate senescent cells that stained blue. The scale bar is $100 \mu \mathrm{m}$. (E): BrdU incorporation into hMSCs was assayed at Days 10 and 50. Each bar represents quantities relative to Day 10 and is the average \pm SD of three wells. (F): hMSCs were detached from the culture dish with trypsin/EDTA after culture at Days 10 and 50, fixed, stained for DNA with PI, and analyzed by flow cytometry (y-axis, cell count; x-axis, PI intensity).

Figure 3. FGF-2 suppresses G1 cell cycle arrest due to passaging. hMSCs were maintained in the medium in the presence or absence of FGF-2 $(1 \mathrm{ng} / \mathrm{ml})$, and total RNAs and proteins were extracted when approaching confluence. (A-C): p16 ${ }^{\mathrm{INK} 4 \mathrm{a}}(\mathrm{A}), \mathrm{p} 53(\mathrm{~B})$, and $\mathrm{p} 21^{\mathrm{Cip} 1}$ (C) mRNA 
expression levels were measured using real time RT-PCR at Days 10 and 50. (D): Total pRB and phospho-pRB proteins detected using Western blot analysis at Days 10 and 50.

Figure 4. FGF-2 increases TGF- $\beta 1$ mRNA expression levels, but does not increase TGF- $\beta 2$ during long-term culture. hMSCs were maintained in the medium in the presence or absence of FGF-2 (1 ng/ml), and total RNAs and proteins were extracted when the cells approached confluence. (A, B): TGF- $\beta 1$ and $\beta 2$ mRNA expression levels were measured using real time RT-PCR at Days 1, 10 and 50. (C): TGF- $\beta 1$ and $\beta 2$ protein expression levels were detected using Western blot analysis at Days 10 and 50 . 


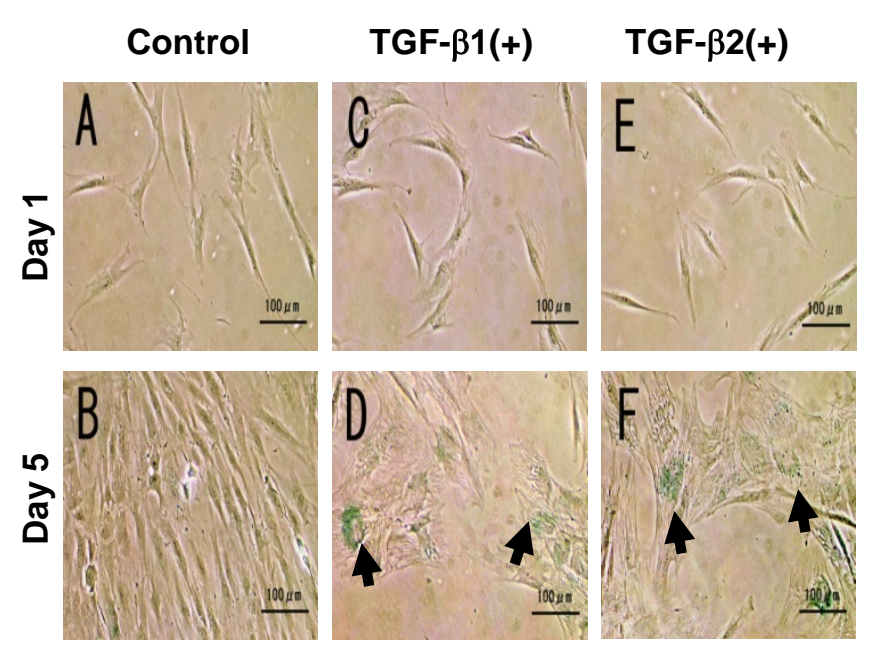

G

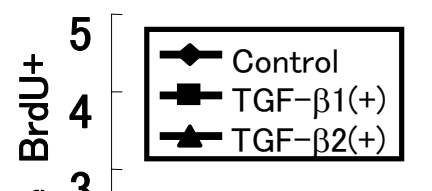

เ 3

要 2

1

0

Day 1 Day 3 Day 5

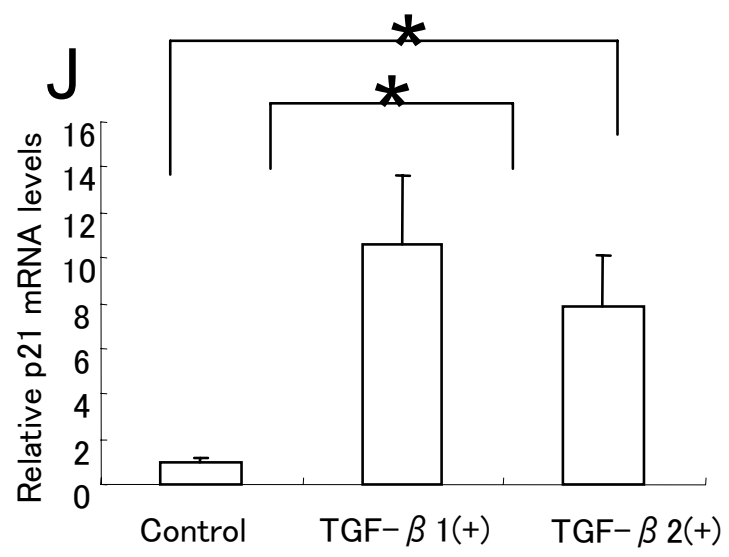

Control TGF- $\beta 1(+)$ TGF- $\beta 2(+)$

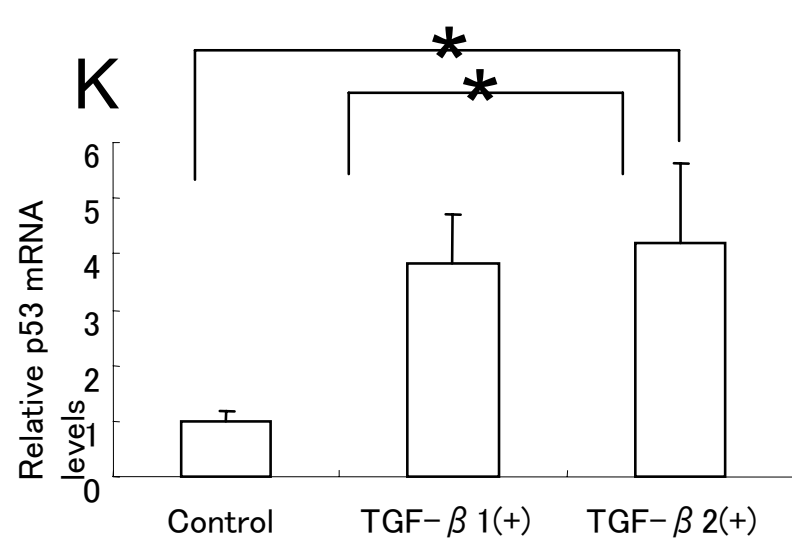

$\mathrm{H}$

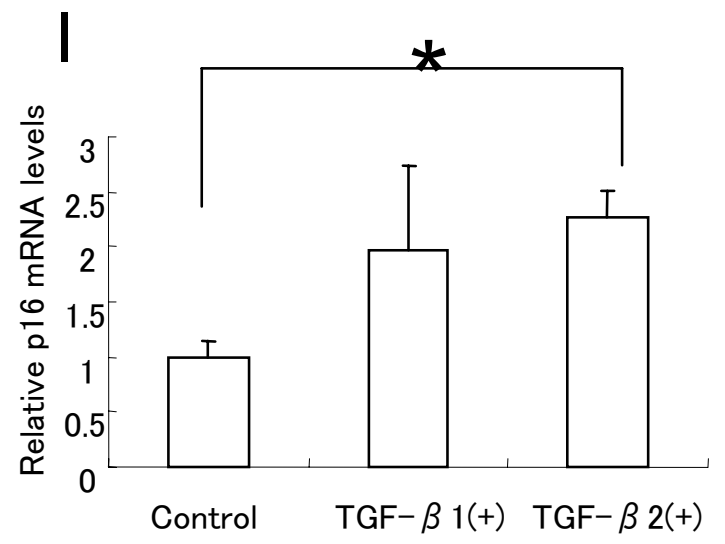

L Control TGF- $\beta 1(+) \quad$ TGF- $\beta 2(+)$

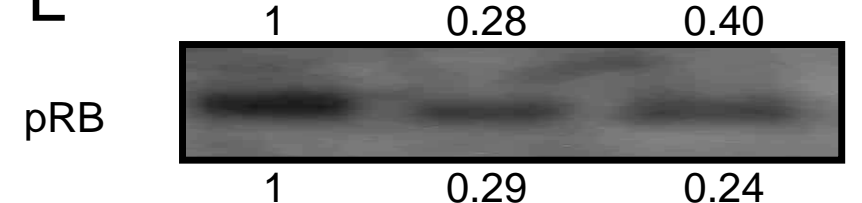

ppRB

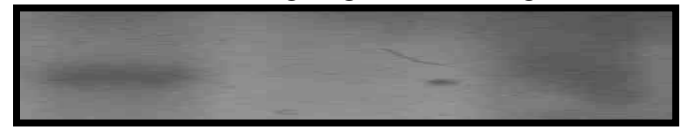

GAPDH
Fig. 1. 
FGF-2(-)

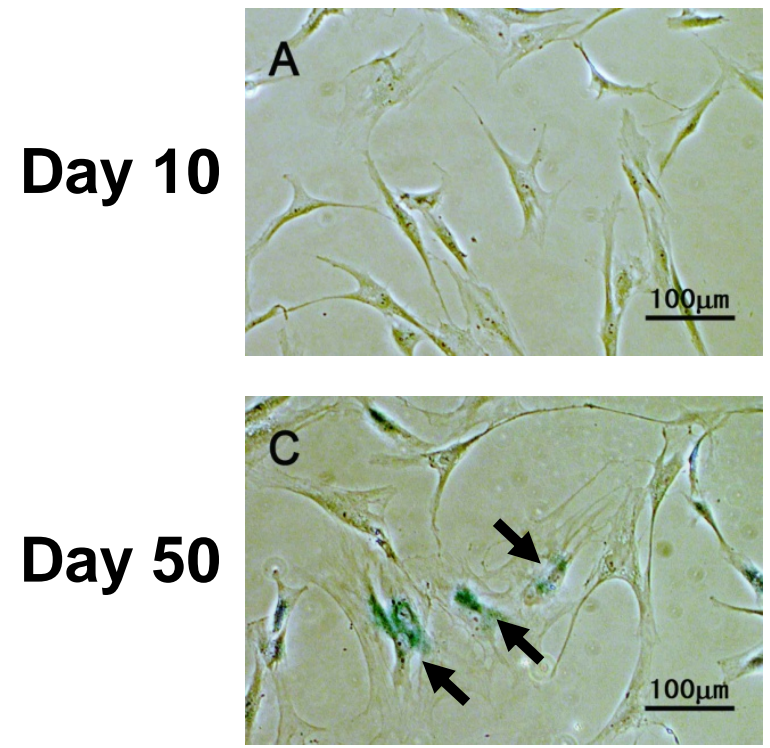

FGF-2(+)

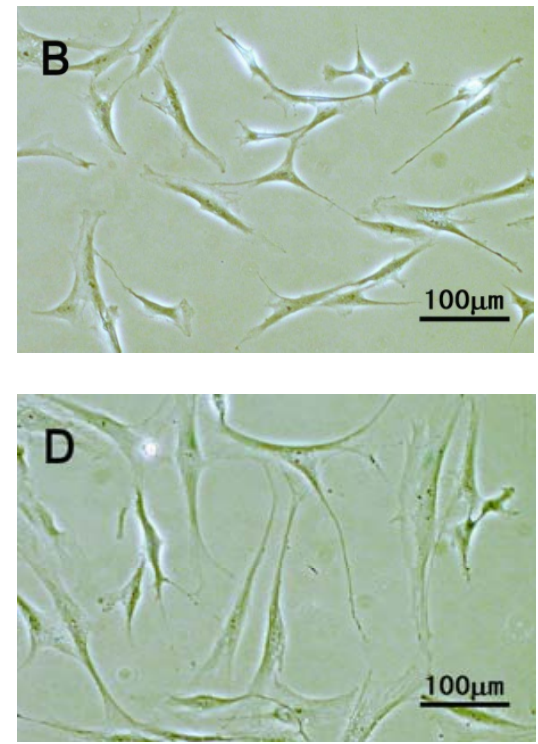

\section{E}

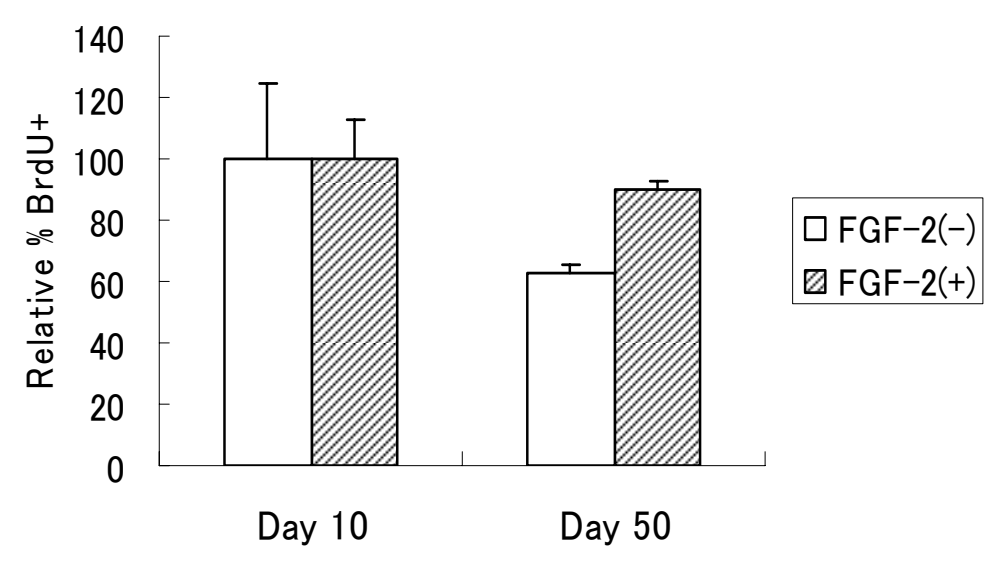

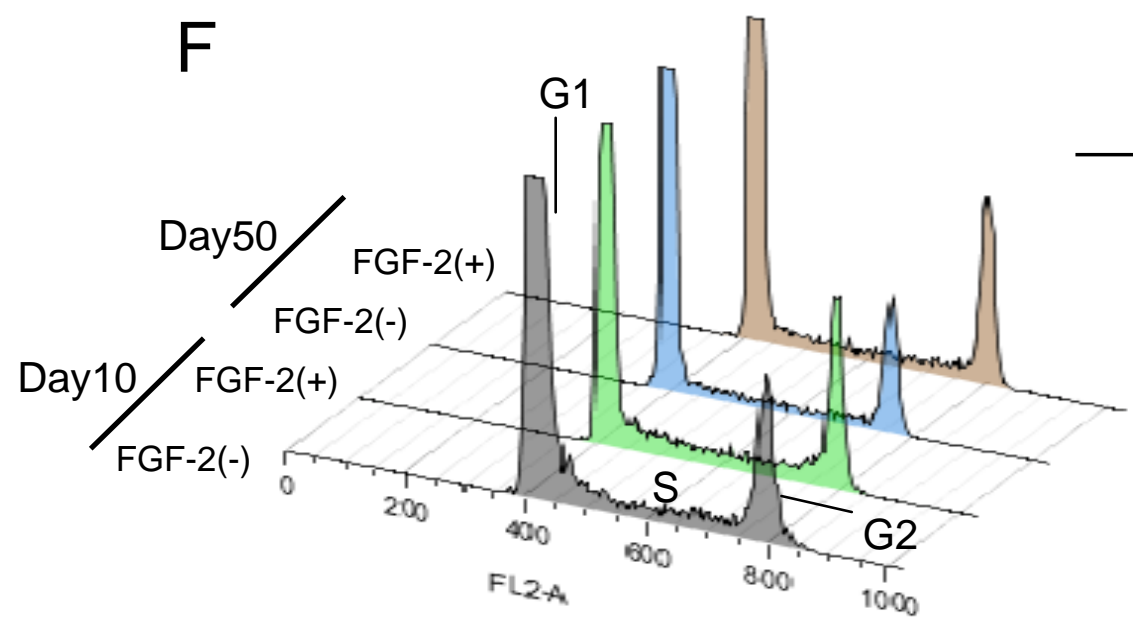

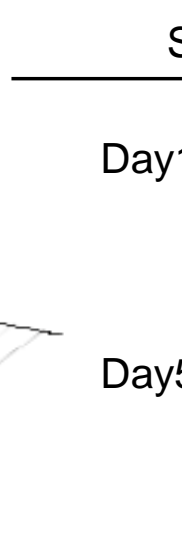

Samples

\%G1

$\% \mathrm{~S}$

\%G2

Day10 FGF-2(-)

74.05

13.95

9.16

FGF-2(+)

72.56

16.58

9.83

Day50 FGF-2(-)

82.42

10.79

5.73

FGF-2(+)

76.60

14.06

8.48

Fig. 2. 

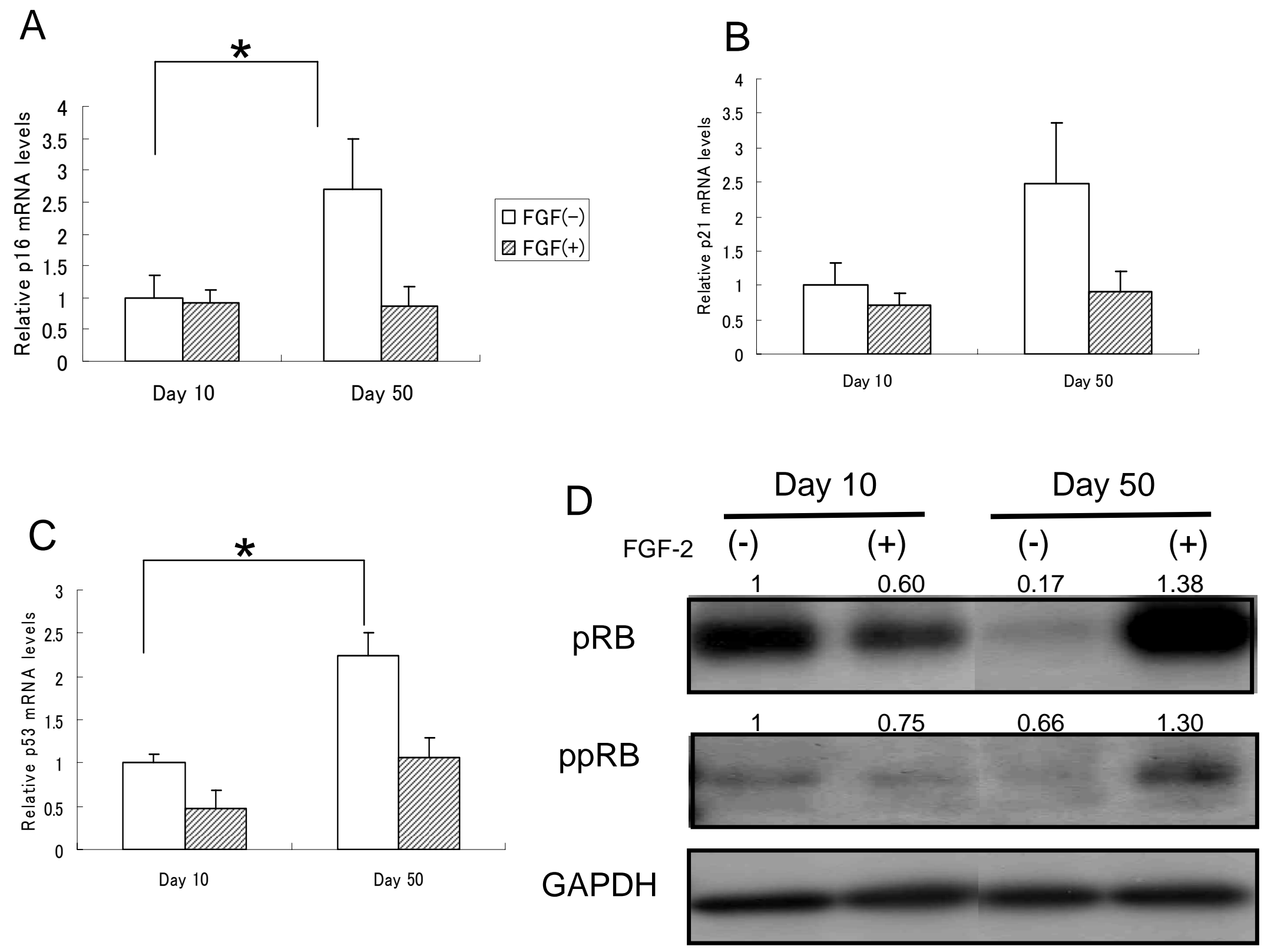

Fig. 3. 

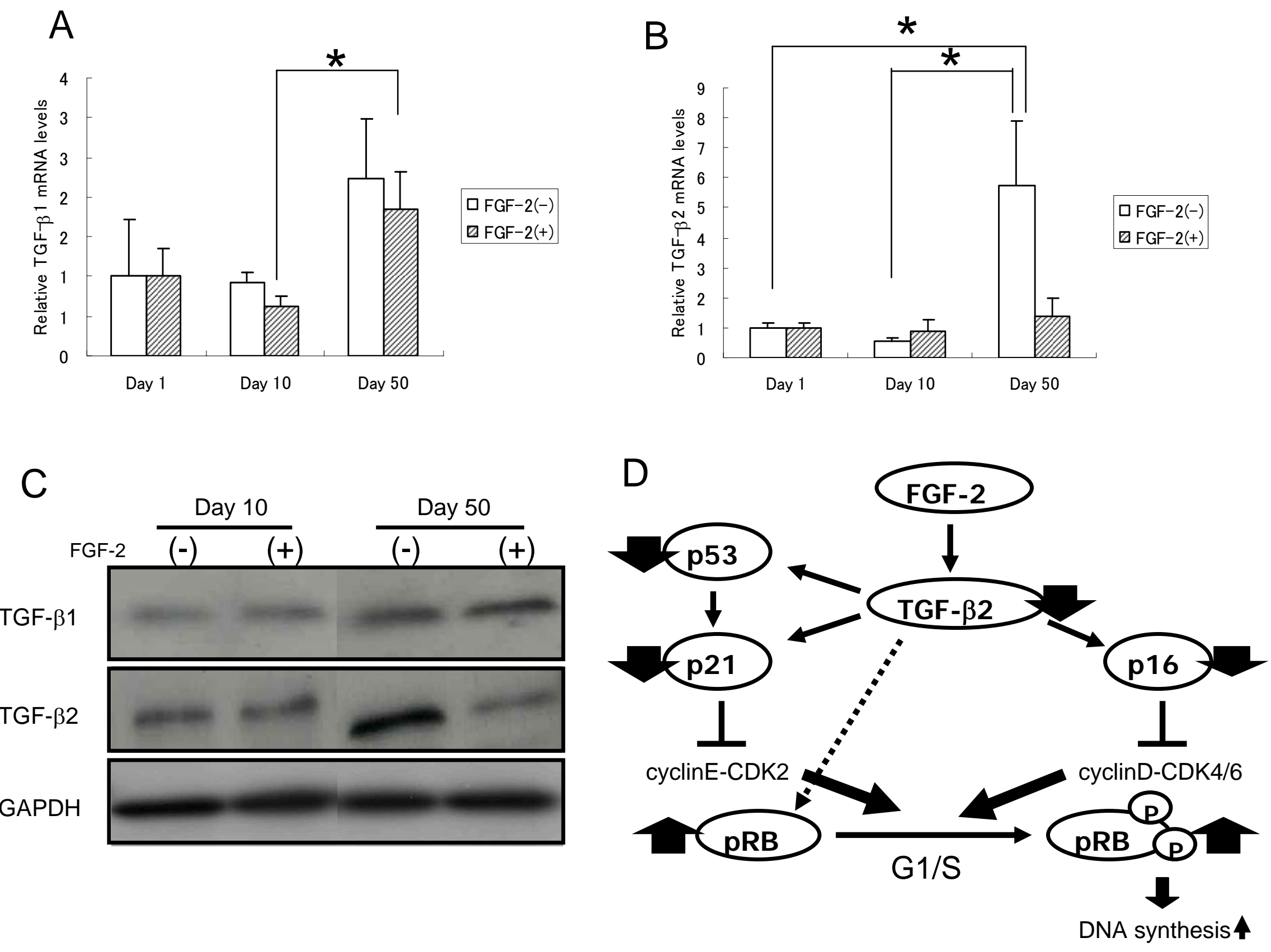

Fig. 4. 